\title{
A MAGYAR FELSŐOKTATÁS 650 ÉVES JUBILEUMA
}

\author{
Per Aspera ad Astra - \\ A Pécsi Tudományegyetem művelődés- és egyetemtörténeti \\ közleményei 4, 1-2. sz. (2017)
}

A pécsi egyetemalapítás 650. évfordulóját számos tudományos és kulturális rendezvénnyel, megemlékezéssel, kiállítással, konferenciával ünnepelték, ${ }^{1}$ a jubileumot publikációk sora kísérte. ${ }^{2} \mathrm{Az}$ intézmény történetét előtérbe helyező kiállítások ${ }^{3}$ és a történettudományi, művelödés-, oktatás- és neveléstörténeti, illetve könyvtártudományi súlypontú, nemzetközi konferencián ${ }^{4}$ elhangzott előadások mellett a Pécsi Tudományegyetem művelődés- és egyetemtörténeti közleményeinek, a Per Aspera ad Astra címü online periodikumnak a teljes negyedik évfolyamát (2017/1-2) is az évfordulóra való emlékezésnek szentelték. A folyóirat történettudományi, társadalom-, tudomány-, oktatás-, nevelés- és művelődéstörténeti eredményeket feltáró kutatásoknak kínál 2014től publikációs lehetőséget, és a közleményeket a beszédek és köszöntők, tanulmányok, visszapillantó, műhely- és szemlerovatokban mutatja be.

A jubileumi kiadványt Vonyó József köszöntőbeszéde nyitja, amellyel a Klimó Könyvtárban megrendezett, Mozaikok a pécsi felsőoktatás múltjából és jelenéböl címü jubileumi kiállítást nyitotta meg 2017. május 31-én. A megnyitó szövegében bemutatja

${ }^{1}$ Vö. Jubileumi krónika, a 650 éves pécsi egyetemalapitás emlékére = Jubilee chronicle, Remembering the foundation of the university 650 years ago (Pécs: Pécsi Tudományegyetem, 2017); Molnár Dávid, „Gondolatok a Pécsi Tudományegyetem jubileuma kapcsán”, Gerundium 9 (2018): 193-201.

2 Fedeles Tamás, Lengvári István, PoHánKa Éva és Polyák Petra, szerk., A pécsi felsőoktatás évszázadai (Pécs: Pécsi Tudományegyetem, 2011); Dezső Krisztina, Lengvári István és Schmelczer-PohánKa Éva, Az egyetemtörténet forrásai (Pécs: Pécsi Tudományegyetem Egyetemi Könyvtár, 2013); SzöGI László, A pécsi felsőoktatás intézményeinek hallgatói (1714) 1782-1852 (Budapest: Eötvös Loránd Tudományegyetem Egyetemi Levéltár; Pécs: Pécsi Tudományegyetem Egyetemi Könyvtár és Tudásközpont, 2016); Lengvári István, szerk., Pécsi egyetemi almanach I. 1367-1950 (Pécs, 2015); Polyák Petra, szerk., Pécsi egyetemi almanach II. 1950-1999 (Pécs, 2017).

3 A Pécsi Tudományegyetem Egyetemi Könyvtár és Tudásközpont vándorkiállítása 650 éves a magyar felsöoktatás - A pécsi egyetemek históriája 1367-töl 2017-ig címmel és az Egyetemi Könyvtár és Tudásközpont Történeti Gyüjtemények Osztályának egyetemtörténeti kiállítása Mozaikok a pécsi felsőoktatás múltjából és jelenéböl címmel.

${ }^{4}$ A konferencia a Pécsi Tudományegyetem Egyetemi Könyvtár és Tudásközpont, az Egyetemi Levéltár és a Bölcsészettudományi Kar Történettudományi Intézet Közép- és Koraújkori Történeti Tanszék szervezésében zajlott University and Universality - the Place and Role of the University of Pécs in Europe from the Middle Ages to Present Day címmel 2017. október 12-13. között. 
a pécsi felsőoktatás mérföldköveit, és hangsúlyozza a pécsi universitas létrejöttének, újraszerveződéseinek és fennállásának szoros kapcsolatát és szimbiózisát az őt körülvevő társadalmi, politikai, ideológiai, gazdasági és kulturális környezettel.

A kötet gerincét a Tanulmányok rovatban szereplő nyolc írás adja. Ebben a rovatban olvashatunk általánosságban a középkori egyetemalapítások körülményeiről és a közép-európai studium generalek fennmaradásának nehézségeiről, illetve részletesen tájékozódhatunk az első magyarországi egyetem születéséről, az intézmény tanárairól és diákjairól és a középkori egyetem épületének lehetséges helyszínéről.

A középkori egyetemekről és az egyetemalapításokról Font Márta tanulmánya értekezik hosszabban. A szerző az európai egyetemalapítások kontextusába helyezve mutatja be a magyarországi egyetemalapítások (Pécs, Óbuda, Pozsony) körülményeit, és elemzi azok rövid fennállásának okait. Különböző szempontokból összehasonlítja a legfrissebb kutatási eredményeket felhasználva a magyarországi egyetemek helyzetét a szomszédos országok közel egy időben alapított egyetemeinek a helyzetével (Prága, Krakkó, Bécs), és jellemzi ezúton a pécsi universitas létrejöttének körülményeit is. A középkori közép-európai egyetemalapításokat bemutató tanulmányt az írások sorrendjét tekintve megelőzi, tartalmát nézve pedig kiegészíti Fedeles Tamás, illetve Haraszti Szabó Péter tanulmánya, amelyek kifejezetten a pécsi universitasra fókuszálnak. Fedeles Tamás a pécsi egyetem alapítási körülményeiről és az egyetemalapítás előkészítéséről ír, és összefoglalja a középkori pécsi egyetem történetére vonatkozó ismereteinket. Hangsúlyozza az intézmény európai jelentőségét, az alapítás körülményeit az egyházmegye és a város történetének szerves részeként mutatja be, tárgyalja a püspökség és a város gazdasági erejének, a székesegyházi iskola és könyvtárának jelentőségét. Részletesen ír Koppenbachi Vilmos püspök közreműködésének a fontosságáról, akinek az egyetem első kancellárjaként többek között szerepe volt az intézmény székhelyének a kiválasztásában és a professzorok javadalmazásában is. Olvashatunk az intézmény professzorairól, feltételezett tanárairól, és egy-két eseményről a diákok életéből. Fedeles kitér az oktatás lehetséges színtereire is és igazolja azt, hogy ahogyan a régió más egyetemei esetében, Pécsett sem járt együtt az egyetemalapítás önálló épületek létesítésével. Fedeles, ahogyan Font Márta is, ezáltal megkérdőjelezi a középkori pécsi egyetem számára felépített épületre vonatkozóan G. Sándor Mária hipotézisét, amely szintén olvasható a kötetben. Fedeles tanulmánya a középkori pécsi egyetem megszűnésének leírásával zárul. Az intézmény Vilmos püspök halála után hanyatlásnak indult és müködése az 1390-es években meg is szűnt.

Haraszti Szabó Péter a középkori pécsi egyetem egy ismeretlen professzorának a nyomába ered. Egy a Cseh Nemzeti Könyvtár Kézirat- és Régi Nyomtatványok Tárában fellelhetö 14. századi kódexben fennmaradt kézirat provenienciája és fennmaradási körülményei alapján lehetségesnek tartja, hogy újabb névvel egészítheti ki az egyetem professzorainak sorát. A kézirat magyarországi kötődésủ másolója, reverendus Buda feltételezhetően az a Budai János, aki az esztergomi Collegium Christi alapítója lesz, és aki Pécsett kezdte tanulmányait, majd azokat a prágai egyetemen folytatta, tanárának 
pedig Prágai Vencel fia Jánost, az egyetem akkori rektorát választotta. Bár csak közvetett adatok állnak rendelkezésre, feltételezhető, hogy Prágai Vencel fia János két, két és fél évig (1369 és 1372 között) Pécsett tartózkodott, javadalmat is kapott és az egyetemen tanított.

A pécsi egyetem feltételezett épületéről, a pécsi Püspökvárról, az Aranyos Máriakápolnáról és a Vilmos püspök síremlékéről értekezik hosszasan G. Sándor Mária a régészeti feltárások és kutatások tükrében. Részletesen tárgyalja a Püspökvár kutatástörténetét az 1930-as évektől kezdve, az eredményeket számos képpel és ábrával illusztrálja. A régészeti feltárások alapján bemutatja a Püspökvár középkori történetét, erődítési rendszerét, a Mária-kápolnát és a püspök síremlékét, illetve meghatározza az egyetem épületének a váron belüli pontos helyét. A feltárás lehetővé tette az egyetem épületének tudományos rekonstrukcióját, és az épületet helyreállító építészek az ásatási eredmények figyelembevételével el tudták készíteni a hiteles műemléki rekonstrukciót is. Ahogyan fentebb említettük, annak bizonyossága, hogy létezett-e egyetemi célra szánt épület, megkérdőjelezhető, de az nem zárható ki, hogy a G. Sándor Mária által feltárt építményben tarthattak egyetemi órákat.

Két tanulmány foglalkozik részletesebben a peregrinációval. Petrovics István tanulmánya a Duna-Tisza-Maros-köz, vagyis a Bánság és annak legjelentősebb városának, Temesvárnak a területére kalauzolja az olvasót. Először bemutatja a terület középkori történetének jellegzetességeit és fordulópontjait, majd az innen származó diákok egyetemjárását vizsgálja a középkori európai egyetemeken, amelynek vonatkozásában több tényezőt tart szükségesnek kiemelni. Egyrészt a tárgyalt területen a Mohács elötti időszakban nem volt királyi szabad és szászok által nagy számban lakott város, illetve a régiót már a 14 . század végén elérte az oszmán pusztítás, így a külföldön tanuló magyarországi diákok közül kevesen származtak ebből a régióból. Kimutatott tény másrészt, hogy a Bánságban élők esetében is a 14. század második felétől figyelhető meg az egyetemjárás. A Duna-Tisza-Maros-köz régiójában összesen négy város (Temesvár, Csanád, Lippa, Karánsebes) található, ahonnan tíznél több diák tanult egyetemen a középkorban. Ezek a diákok a bécsi és a krakkói egyetemeket részesítették előnyben. Temesvár 4000 lakosú városából 1552-ig 61 diák tanult külföldi egyetemeken. A szerző tanulmányát a Bécsben és a Krakkóban tanult temesvári származású diákok névlistájával zárja, amely része a Szögi László által indított peregrinációkutatás eredményeként létrehozott egységes adatbázisnak, és tartalmazza a hallgatók származási helyét, társadalmi állását, a fakultások nevét, a tanulmányaik idejét, a tudományos fokozatokat, illetve a korábban látogatott egyetem(ek) neveit, és ahol lehetséges, további életpályát is közöl.

Kelényi Borbála a magyarországi diákok jelenlétét tárgyalja részletesen a Bécsi Egyetemen, és bemutatja, mely karokat részesítették előnyben a diákok, illetve tájékoztat a fokozatszerzésekről is. A tanulmány forrásai azok a közelmúltban elkészült adattárak, amelyek tartalmazzák a bécsi és a krakkói egyetemekre beiratkozott magyarországi diákok névsorát. Kelényi Borbála tanulmányának újdonsága az, hogy a Bécsi Egyetemre 
vonatkozó anyakönyvi adatokat és promoválási névlistákat tartalmazó korábbi és újabb adattárakat és adatbázisokat felhasználva kitűnő áttekintést nyújt a fakultásválasztásokról és a fokozatszerzésekről. A Bécsi Egyetem vizsgálata abból a szempontból is szerencsés, hogy ezen a magyarországi diákok által leglátogatottabb egyetemen mind a négy fakultás vizsgálható volt. A szerző az 1365-1526 időszakra vonatkozóan 6785 személyben állapította meg a Bécsi Egyetem Hungarusainak a számát, akik közül 2107 diák karválasztásáról rendelkezünk információkkal. Az artes fakultás volt a legkedveltebb 1921 fővel, amelyet a jogi fakultás követett 349 fövel. Az orvosi és a teológiai kar látogatottsága 18 és 35 fővel elenyésző volt. A szerző írását számos informatív grafikonnal gazdagítja, amelyek karokra bontva mutatják be a beiratkozásokat és a fokozatszerzéseket.

A tanulmányok sorát Pieter Dhondt és Szögi László írásai zárják, amelyek az egyetemtörténet-írás elméleti és történeti kérdésfelvetéseit tárgyalják. Pieter Dhondt szövege egy tanulmánykötet ${ }^{5}$ bevezetője, amely az egyetemtörténet-írás és az egyetemi jubileumok közötti hagyományosan szoros kapcsolatból eredő kérdéseket és problémákat helyezi a középpontba. Az évfordulók szerepét vizsgálja, és különböző európai egyetemek történetére fókuszáló kutatások, workshopok, konferenciák eredményeit és módszertanát bemutatva összehasonlító vizsgálatot végez a hasonlóságokat és a különbözőségeket, illetve az előnyöket és a hátrányokat összevetve. A szerző hangsúlyozza, hogy a jubileumi történetírás továbbra is jelentős dominanciája mellett az egyetemtörténet-írás fokozatosan három irányban szélesedett ki, horizontja földrajzi, tematikai és kronológiai értelemben tágult. Kiemeli, hogy az egyetemtörténetnek - bizonyos mértékben legalábbis - még emancipálódnia kell az egyetemi jubileumok kultúrájától, és fontosnak tartaná, ha közelebbi kapcsolatba kerülhetne a nevelés- és oktatástörténettel, amelynek fogalomhasználatából és módszertanából profitálhatna. A tanulmánykötetről egyébként ismertetést olvashatunk a most bemutatandó folyóiratszám szemléző rovatában, illetve tájékozódhatunk Bitskey István írásából is a Gerundium korábbi számában. ${ }^{6}$

Szögi László a magyarországi kutatási irányokról és azok eredményeiről számol be a magyar egyetemtörténet-írás utóbbi 25 évét bemutatva. Felvázolja a történeti Kárpát-medence területén alapított egyetemek történetét vizsgáló kutatások fejlődését, részletesen felsorolja és véleményezi az egyetemtörténeti kutatások forrásdokumentumait feltáró kiadványokat, az egyetemtörténeti monográfákat. Kiemelten szól a magyarországi felsőoktatás történeti forrásainak fellelhetőségéről, az egyetemjárásokról és a magyarországi felsőoktatás döntő jelentőségű korszakairól. Bár a hazai felsőoktatás múltjának szakszerủ feldolgozásában pozitív folyamat indult el, a kutatási és a publikálási lehetőségek biztató irányt vettek, számos időszak és terület van még, amelyek még részletesebb vagy objektív feldolgozásra várnak. A jövőre nézve fontosnak tartja

\footnotetext{
${ }^{5}$ Pieter Dhondt, ed., University Jubilees and University History Writing: A Challenging Relationship (Leiden-Boston, 2015).

${ }^{6}$ Gerundium 8 (2017): 147-152.
} 
az államszocializmus időszakának már elkezdődött és mérvadó kutatásának folytatását, illetve szorgalmazza a diákélet és a diákegyesületek területén folyó vizsgálódásokat és kutatásokat.

A Mühely című rovat négy írást és egy bibliográfiát tartalmaz. Első darabja követi az egyetemtörténet-írás és a jubileumok kapcsolatát vizsgáló szempontokat, és a pécsi középkori egyetemet vizsgáló kezdeményezéseket és kutatásokat mutatja be az elmúlt ötven évre vonatkozóan. Számba veszi az említésre méltó kezdeményezéseket és eredményeket a középkori pécsi egyetem alapításának 600. évfordulójához kapcsolódó jubileumi ünnepségektől (1967), kezdve a költő és fôpap halálának 500. évfordulója alkalmából rendezett Janus Pannonius-megemlékezéseken át (1972) a Pécsi Egyetemi Könyvtár alapításának 200. évfordulójáig (1974). A 600 éves jubileum előtti időszakból is kiemel olyan írásokat, amelyek egyetemtörténeti szempontból fontosak. A jubileumok esetében részletesen tárgyalja az előkészületi munkákat, magukat az eseményeket és az értékeléseket. Hosszasan értekezik a középkori egyetem épületének lehetséges helyére vonatkozó állásfoglalásokról is. Petrovics Ede, G. Sándor Mária és munkatársa Gerő Győző véleményeinek ismertetése mellett megemlíti mások hozzájárulását is a témához. Szól Vörös Márton egykori pécsi levéltár-igazgató, Rajczi Péter tanár és levéltáros és Sárközy Péter italianista nézeteiről és érveiről. Minden lehetséges műfajt felsorol, amelyben a középkori egyetemre vonatkozó megnyilvánulásokat, hozzájárulásokat talál, így a tanulmányok és cikkek mellett számba veszi a konferenciákat, a kiállításokat, a forráskiadást, a tanulmányköteteket, a tematikus folyóiratszámokat. Kiemelendő, hogy az Egyetemi Könyvtár tudományos hozzájárulását sem hagyja ki. Boda Miklós széles spektrumban mutatja be a tudományos szférában az elmúlt fél évszázadban történteket a pécsi studium generaléval kapcsolatban, írását a jelenkori jubileummal zárja. Irodalomjegyzéke gazdag bibliográfiát ad a középkori pécsi egyetem történetének és kutatásának a tanulmányozásához. Ezt a jegyzéket jól kiegészíti a rovatban a középkori pécsi egyetem válogatott, 144 tételes bibliográfiája, amelyet Kerekes Imre állított össze.

Schmelczer-Pohánka Éva igen érdekes adalékkal szolgál, miközben annak a legendának a nyomába ered, amely szerint a mohácsi csatában 300 pécsi egyetemi hallgató lelt hősi halált. Arra keresi a választ, miként keletkezett és maradt fenn ez a 16. századra vonatkozó történet a pécsi egyetem 1390-es években történt valószínủ megszűnése ellenére. A korabeli források vizsgálatától kezdve követi a történet fellelhetőségét, felfelbukkanását, és megállapítja, hogy a legenda születése és a hagyomány elterjedése a 18. század elejére tehető. Timon Sámuel jezsuita történettudós 1715-ben kiadott, Synopsis novae chronologiae regnorum Hungariae, Croatiae, Dalmatiae címü munkájával kezdődően a köztudatban folyamatosan élénken élt a történet. Bár a 19. század elején Koller Józsefnél már felbukkan a tények megkérdőjelezése, még a századfordulón is kész tényként fogadták el a történetet. A későbbiekben megcáfolt tények továbbélését és legendává válását segítette egy tárgyi emlék is, az 1774-ben alapított pécsi püspöki könyvtárban leltárba vett egyik zászlórúd. A zászló(rúd) első részletes leírása a 20. 
századból származik, amelyben az áll, hogy a hagyomány szerint alatta esett el 1526ban Mohácsnál a 300 pécsi hallgató. A zászlónyélhez kapcsolódó mítosz is élénken tovább élt, a zászlónyélről és a hallgatók elestéről több költeményben is megemlékeztek. A pécsi hallgatóknak a mohácsi csatában való részvételét idővel megcáfolták, a zászlónyelet figyelmetlen módon partvisnyélnek befaragták és mai fellelhetősége ismeretlen, ám mindkét történet szép példája a hazafias hagyományteremtésnek. SchmelczerPohánka Éva írásának értékét emeli a legenda levéltári és nyomtatott forrásainak az összegzése.

Tóthné Radó Cecília írása a kéziratok, a kompiláció és a prédikációk területére kalauzolja az olvasót. A szerző az ún. Pécsi prédikációvázlatok elemzésére vállalkozik, hogy kimutathassa, Pécsett a 15. század végén egy rendkívül tájékozott és magas műveltségü prédikátor töltötte be a hivatalos hitszónoki pozíciót. Egy, a Pécsi Egyházmegye tulajdonában lévő ősnyomtatványról, Robertus Caracciolus Sermones de laudibus sanctorum címủ művének Velencében 1489-ben Georgius Arrivabenus által kiadott egyik példányáról van szó, amelynek különleges értékét a benne található számtalan kéziratos bejegyzés és egy kéziratos függelék adja. Az ősnyomtatvány utolsó lapjain olyan prédikációk vázlatai találhatóak, amelyek valós időben, valós helyszínen és valós közönség előtt hangzottak el, Pécsett 1495-ben és 1496-ban. A szerző számba veszi mindazon műveket, amelyeket a prédikátor a rövid sermo-vázlatokban felsorolt, és így vizsgálni tudja az anyaggyüjtés mikéntjét, a választott források korszerűségét és igényességét, illetve a választott források feldolgozásának módjait is. Ez képet ad a korabeli prédikátor műveltségéről és egyben lehetőségeiről is, valamint bizonyítja, hogy egyértelműen ferences hagyományból táplálkozott, de személyének pontosítására nem ad lehetőséget.

Oroszi Sándor írása Abay (Neubauer) Gyula akadémiai levelező tag, dékán, tanszékvezető tevékenysége előtt kíván tisztelegni születésének 125. évfordulója alkalmából. A Pécsi Tudományegyetem néhai közgazdászprofesszorának életéből és tudományos munkásságából a fordulópontokat kiemelve felvázolja a tudós és oktató pályaívét. Abay (Neubauer) Gyula, akinek a szerző a felkészültségét és az emberi tartását hangsúlyozza, a váci börtönben fogalmazta és írta meg - minden forrásanyag felhasználását nélkülözve - régi elképzelését, az örök gazdaságtan rendszerét. Oroszi Sándor gondolatmenetében a tudós életének és munkásságának a fordulópontjai a Pécsi Tudományegyetem, illetve tágabban a magyar társadalom vázlatos leírását adják.

A Visszapillantó címet viselő rovat interjúkat, riportokat, visszaemlékezéseket, beszélgetéseket tartalmaz. Jelen kötet számára Dezső Krisztina és Gergely Zsuzsanna készítettek interjút Nagy Imre pécsi professzorral. Az irodalmár professzor személyes élményei egyfajta szubjektív múltrekonstrukcióként működnek és egyéni perspektívából világítják meg a korabeli pécsi oktatás, művelődés és kultúra helyzetét, ezzel is árnyalva a városról és oktatási intézményeiről alkotott képünket.

A Szemle rovatban három könyv ismertetését olvashatjuk. Barabás Gábor a Haraszti Szabó Péter, Kelényi Borbála és Szögi László szerzőségében megjelent Magyar- 
országi diákok a prágai és krakkói egyetemeken 1348-1525 címü kiadvány első kötetét méltatja, amely mü mindkét kötetéről már olvashattunk korábban egy értékelő írást folyóiratunkban Bozzay Réka tollából.7 A második ismertetés, Polyák Petra írása a Pieter Dhondt által szerkeszett, fentebb említett tanulmánykötetről szól. A harmadikként, Sztana-Kovács Adrienn által bemutatott könyv - Tomás Irish Trinity in War and Revolution 1912-1923 című munkája - az elözőhöz hasonlóan az egyetemtörténet-írás problémakörét boncolgatja.

Összességében az igényesen szerkesztett folyóiratszám méltó médiuma a 650 éves jubileum megünneplésének. A részletes és alapos tanulmányok kimerítő tényanyaggal gazdagítják a pécsi universitasra, a középkori egyetemalapításokra és egyetemjárásokra, illetve a korabeli felsőfokú oktatás helyzetére vonatkozó ismereteinket. Fedeles Tamás, Font Márta, Haraszti Szabó Péter, Kelényi Borbála és Szögi László tanulmányaiban publikált nemzetközi értékű eredmények angol, illetve német nyelven is megjelentek a jubileumi konferenciakiadványban, ${ }^{8}$ így nemzetközi szinten is tájékoztatják a tudományos közösséget a magyarországi és a történeti Magyarországra vonatkozó egyetem- és tudománytörténeti kutatásokról, eredményekről, forrásokról. A folyóiratban megjelent írások a konferencia tanulmányaihoz képest részletesebb információkat tartalmaznak a régészeti kutatásokról. A Mühely és a Visszapillantó rovatok írásai értékes művelődés- és kortörténeti hozzájárulást jelentenek a pécsi egyetem 650 éves történetéhez, a személyes visszaemlékezéseket tartalmazó írások pedig közvetlenebbé teszik az „egyetemélményt" a befogadó számára.

L. Szögedi Gabriella

7 Gerundium 9 (2018): 149-153.

8 University and Universality, The Place and Role of the University of Pécs in Europe from the Middle Ages to Present Day, International University History Conference 12-13 October 2017 Pécs, ed., Ágnes Fischer-Dárdai, István Lengvári, Éva Schmelczer-Pohánka (Pécs: University Library of Pécs and Centre of Learning, 2017) 